\title{
Effect of Time and Concentration on Mortality of the Cigarette Beetle, Lasioderma serricorne (F.), Fumigated With Phosphine*
}

\author{
by \\ Naoto Fukazawa and Ryota Takahashi \\ Leaf Tobacco Research Center, Japan Tobacco Inc., Idei 1900, Oyama, Tochigi 323-0808, Japan
}

\section{SUMMARY}

The efficacy of a fumigant is determined by the gas concentration and exposure time. Typically, the gas concentration and exposure time are equally important in fumigation efficacy and their relationship is expressed as $C t=k$, where $C$ is the concentration, $t$ is the time and $k$ is a constant (Haber's rule). However, deviation from Haber's rule, i.e., the relative importance of time over concentration, has been reported for several stored-product pests, and a modified form $\left(C^{n} t=k\right)$ is used to express the relationship between $C$ and $t$. This study aimed to determine if this modified form could be applied to phosphine fumigation of the cigarette beetle, Lasioderma serricorne (F.). Adult beetles from six cultures with different phosphine-resistance levels were exposed to phosphine (1-2000 ppm) at $25^{\circ} \mathrm{C}$ for either $24,72,120$, or $168 \mathrm{~h}$, and the phosphine concentration necessary to achieve $50 \%$ lethality $\left(\mathrm{LC}_{50}\right)$ was calculated. The phosphine concentration $(C)$ and the exposure time $(t)$ relationship at the $\mathrm{LC}_{50}$ for all six cultures were determined by regression analyses. The equation $C^{n} t=k$ was a good fit for all the cultures tested, irrespective of phosphine resistance. The results showed the exponent $n$ was less than 1 ( $0.51 \leq n \leq 0.71$, coefficient of determination 0.90-0.99), suggesting that time is more important than concentration in toxicity expression of phosphine against $L$. serricorne. Therefore, extending the exposure time rather than increasing the concentration should be emphasized to manage the future threat of resistance problems with phosphine. [Beitr. Tabakforsch. Int. 27 (2017) 97-101]

\section{ZUSAMMENFASSUNG}

Die Wirksamkeit eines Begasungsmittels wird anhand der Gaskonzentration und der Expositionsdauer bestimmt. In der Regel sind die Gaskonzentration und Expositionszeit für die Wirksamkeit der Begasung gleichermaßen bedeutsam, und ihr Verhältnis wird als $C t=k$ ausgedrückt, wobei $C$ die Konzentration, $t$ die Dauer und $k$ eine Konstante (Habersche Regel) ist. Dennoch wurde bei mehreren Vorratsschädlingen eine Abweichung von der Haberschen Regel, d.h. die relative Bedeutung der Dauer im Vergleich zur Konzentration, berichtet, und es wird eine modifizierte Form $\left(C^{n} t=k\right)$ verwendet, um das Verhältnis zwischen $C$ und $t$ auszudrücken. Ziel dieser Studie war es zu untersuchen, ob diese modifizierte Form auf die Begasung des Tabakkäfers Lasioderma serricorne (F.) mit Phosphin angewendet werden könnte. Erwachsene Käfer aus sechs Kulturen mit unterschiedlichem Phosphin-Resistenzniveau wurden bei $25^{\circ} \mathrm{C}$ entweder $24,72,120$ oder $168 \mathrm{~h}$ gegenüber Phosphin (1-2000 ppm) exponiert, und es wurde die für eine 50\%ige Letalität notwendige Phosphin-Konzentration $\left(\mathrm{LC}_{50}\right)$ berechnet. Das Verhältnis von PhosphinKonzentration $(C)$ und Expositionsdauer $(t)$ bei $\mathrm{LC}_{50}$ wurde mithilfe von Regressionsanalysen jeweils für alle sechs Kulturen ermittelt. Die Gleichung $C^{n} t=k$ eignete sich gut für alle getesteten Kulturen, unabhängig von der PhosphinResistenz. Die Ergebnisse zeigten, dass der Exponent $n$ weniger als $1(0.51 \leq \mathrm{n} \leq 0.71$, Bestimmtheitsma 0.90-0.99) betrug und darauf hindeutet, dass die Dauer für die Toxizitätsexpression von Phosphin gegen $L$. serricorne wichtiger ist als die Konzentration. Daher sollte anstelle 
einer höheren Konzentration besser eine Verlängerung der Expositionsdauer empfohlen werden, um dem drohenden Resistenzproblem mit Phosphin zu begegnen. [Beitr. Tabakforsch. Int. 27 (2017) 97-101]

\section{RESUME}

L'efficacité d'un fumigant dépend de la concentration gazeuse et du temps d'exposition. D'ordinaire, la concentration gazeuse et le temps d'exposition revêtent une importance égale pour une fumigation efficace et leur rapport est noté $C t=k$, sachant que $C$ désigne la concentration, $t$ désigne le temps et $k$ est une constante (règle de Haber). Cependant, une entorse à la règle de Haber, à savoir l'importance relative du temps sur la concentration, fut observée sur plusieurs nuisibles présents dans les produits entreposés et une formule modifiée $\left(C^{n} t=k\right)$ fut utilisée pour exprimer le rapport entre $C$ et $t$. La présente étude vise à déterminer si cette formule modifiée pourrait être appliquée à la fumigation au gaz phosphine du coléoptère des cigarettes, Lasioderma serricorne (F.). Des coléoptères adultes provenant de six cultures distinctes et présentant des niveaux différents de résistance à la phosphine furent exposés au gaz phosphine (1-2000 ppm) porté à $25^{\circ} \mathrm{C}$ durant des périodes de $24,72,120$ ou 168 heures et le calcul fut effectué de la concentration en phosphine nécessaire pour atteindre un taux de $50 \%$ de létalité $\left(\mathrm{LC}_{50}\right)$. Les rapports entre la concentration en phosphine $(C)$ et le temps d'exposition $(t)$ à une létalité de $\mathrm{LC}_{50}$ pour la totalité des six cultures furent déterminés par des analyses de régression. L'équation $C^{n} t=k$ s'avéra bien convenir à toutes les cultures testées, quelle que soit leur résistance à la phosphine. Les résultats montrèrent que l'exposant $\mathrm{n}$ était inférieur à $1(0.51 \leq \mathrm{n} \leq 0.71$, coefficient de détermination 0.90-0.99), laissant à penser que le temps prime sur la concentration dans l'expression de la toxicité de la phosphine envers le L. serricorne. Par conséquent, prolonger le temps d'exposition plutôt qu'augmenter la concentration devrait être recommandé afin de gérer la future menace d'une résistance problématique à la phosphine. [Beitr. Tabakforsch. Int. 27 (2017) 97-101]

\section{INTRODUCTION}

The efficacy of a fumigant is determined by the concentration of gas and exposure time. For most fumigants, such as methyl bromide, the relationship between gas concentration and exposure time to produce a certain mortality is expressed by Haber's rule, $C t=k$, where $C$ is the gas concentration, $t$ is the exposure time, and $k$ is a constant (1). In Haber's rule, both the gas concentration and exposure time contribute equally to the fumigation efficacy, that is, doubling the gas concentration will halve the exposure time required to achieve the same effect and vice versa. For phosphine fumigation, deviation from Haber's rule has been reported for several stored-product pests, including Tribolium castaneum (Herbst) (2, 3), Ephestia elutella (Hübner) $(4,5)$, Liposcelis entomophila (Enderlein) (6). In these cases, gas concentration and exposure time are not of equal importance. Instead, the exposure time is more important, and the relationship can be expressed as $C^{n} t=k$, where $n$ is less than 1 (2).

Phosphine resistance in L. serricorne was first recorded in India and the United States in the 1990s (7, 8), and has spread globally with international tobacco distribution. The tobacco industry has managed the resistance problem by both extending the exposure time and increasing the concentration. They have been aware that extended exposures are much more effective against the resistant beetles than higher concentrations alone (9). However, to date, there has been no experimental evidence to support this focus on the exposure time.

The aim of the present study was to determine if the $C^{n} t=k$ relationship is applicable to phosphine fumigation of $L$. serricorne, regardless of the level of resistance. The findings will provide a basis for managing future resistance problems with this species.

\section{MATERIALS AND METHODS}

\section{Insects}

Six laboratory cultures of L. serricorne were used in this study (Table 1). These cultures were maintained on cornmeal containing yeast ( $10 \%$ mass fraction) at $27{ }^{\circ} \mathrm{C}, 60 \%$ relative humidity $(\mathrm{RH})$, and with a photoperiod of 12:12 (light:dark). Preliminary tests revealed the presence of heterogeneity in levels of resistance between individuals within the respective cultures. The susceptible insects, in the five resistant cultures, were eliminated by exposures to phosphine at the egg stage. The exposure was conducted for six consecutive generations at their respective $72-\mathrm{h} \mathrm{LC}_{50}$ levels at $25^{\circ} \mathrm{C}$ as shown in Table 1 .

Table 1. Lasioderma serricorne cultures used in the study and phosphine concentrations required to achieve $50 \%$ lethality ( $\left.\mathrm{LC}_{50}\right)$ for eggs at $72-\mathrm{h}$ exposure, $25^{\circ} \mathrm{C}$, and $75 \%$ relative humidity that respective cultures originally posessed.

\begin{tabular}{l|c|ll}
\hline Culture & $\begin{array}{c}\text { Start of } \\
\text { culturing }\end{array}$ & & $\begin{array}{c}\text { Phosphine } \\
\text { Origin } \\
\text { for eggs } \\
(\mathrm{ppm})\end{array}$ \\
\hline TSC & Unknown & Phosphine-susceptible laboratory culture & \\
THR & 1999 & Phosphine-resistant population collected in a tobacco warehouse in Tokyo, Japan & 7.2 \\
IWT & 1999 & Phosphine-resistant population collected in a tobacco warehouse in Shizuoka, Japan & 7.5 \\
NGY & 1997 & Phosphine-resistant population collected in a tobacco warehouse in Aichi, Japan & $\begin{array}{l}\text { 147.9 } \\
\text { C87 }\end{array}$ \\
SM & 2011 & Phosphine-resistant population provided by Food and Environment Research Agency (York, UK) & 136.6 \\
\hline
\end{tabular}




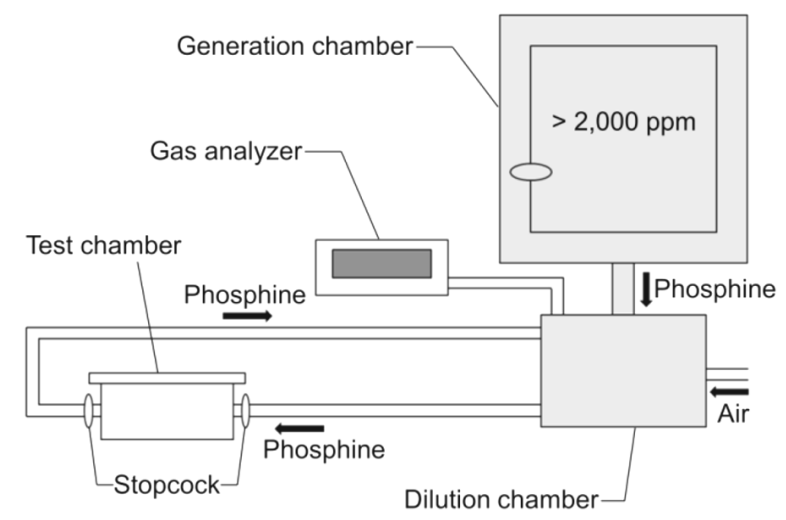

Figure 1. Fumigation test apparatus. Phosphine (> $2000 \mathrm{ppm})$ was generated from aluminum phosphide in a generation chamber and adjusted to a predetermined concentration in a dilution chamber using a gas analyzer. The gas was then introduced into a test chamber containing the insects. After gas introduction, the test chamber was detached from the system and placed into an incubator at $25^{\circ} \mathrm{C}$.

\section{Phosphine-susceptibility testing}

The phosphine susceptibility of adults was evaluated according to the method describe by HORI and KASAISHI
(10), except for exposure time. Fifty adults were collected within $3 \mathrm{~d}$ of emergence and placed in polystyrene vials (ø $25 \mathrm{~mm}$, height $50 \mathrm{~mm}$ ) sealed with fine wire mesh allowing movement of gases but preventing escape of the insects. The vials were placed in a polyvinyl chloride chamber $(160 \times 295 \times 100 \mathrm{~mm})$ connected to fumigation apparatus (Kanto Kogyo Co., Ltd., Kanagawa, Japan) (Figure 1). Phosphine was generated from aluminum phosphide Tyvek $^{\circledR}$; Degesch Japan Co., Ltd., Saitama, Japan) and introduced into the test chamber after adjusting the concentration (1-2000 ppm) using a phosphine gas analyzer (Komyo Rikagaku Kogyo K.K., Kanagawa, Japan).

A container of a saturated solution of sodium chloride was placed in the test chamber to maintain the $\mathrm{RH}$ at $75 \%$. The adults were exposed to phosphine at $25^{\circ} \mathrm{C}$ for 24,72 , 120 , or $168 \mathrm{~h}$. After exposure, the adults were maintained at $27{ }^{\circ} \mathrm{C}, 60 \% \mathrm{RH}$, and with a photoperiod of $12: 12$ (light:dark) for $2 \mathrm{~d}$. Their viability was assessed based on locomotion, and paralyzed adults were considered to be dead.

\section{Data analysis}

Phosphine concentrations to achieve $50 \%$ lethality $\left(\mathrm{LC}_{50}\right)$ were calculated using the PriProbit (ver. 1.63) computer program developed by SAKUMA (11).

For each culture the $\mathrm{LC}_{50}$ values for the fixed time periods were used to estimate the regression equation $C^{n} t=k$ using Microsoft Excel 2010.

Table 2. Phosphine concentrations required to achieve $50 \%$ lethality $\left(\mathrm{LC}_{50}\right)$ for adults of Lasioderma serricorne cultures exposed to phosphine for either $24,72,120$, or $168 \mathrm{~h}$ at $25^{\circ} \mathrm{C}$ and $75 \%$ relative humidity.

\begin{tabular}{|c|c|c|c|}
\hline Culture & Exposure time $(\mathrm{h})$ & Slope \pm SE & $\mathrm{LC}_{50}(95 \%$ confidence interval $)(\mathrm{ppm})$ \\
\hline \multirow[t]{4}{*}{ TSC } & 24 & $3.44 \pm 0.27$ & $17.8(15.8-20.1)$ \\
\hline & 72 & $3.94 \pm 0.62$ & $4.6(3.8-5.4)$ \\
\hline & 120 & $2.11 \pm 0.14$ & $3.0(2.6-3.3)$ \\
\hline & 168 & $1.98 \pm 0.42$ & $0.6(0.2-1.0)$ \\
\hline \multirow[t]{4}{*}{ THR } & 24 & $1.64 \pm 0.14$ & $316.4(257.5-393.5)$ \\
\hline & 72 & $3.06 \pm 0.33$ & $50.2(41.4-59.8)$ \\
\hline & 120 & $1.90 \pm 0.14$ & $41.0 \quad(35.1-47.7)$ \\
\hline & 168 & $3.06 \pm 0.24$ & $18.2(15.9-20.5)$ \\
\hline \multirow[t]{4}{*}{ IWT } & 24 & $1.67 \pm 0.11$ & $654.0(559.2-779.9)$ \\
\hline & 72 & $2.66 \pm 0.39$ & $94.6(72.5-123.1)$ \\
\hline & 120 & $1.87 \pm 0.14$ & $60.6(52.1-71.0)$ \\
\hline & 168 & $2.64 \pm 0.24$ & $38.1 \quad(32.2-45.1)$ \\
\hline \multirow[t]{4}{*}{ NGY } & 24 & $1.69 \pm 0.13$ & $631.5(526.9-776.4)$ \\
\hline & 72 & $2.40 \pm 0.30$ & $110.7(87.4-142.0)$ \\
\hline & 120 & $1.88 \pm 0.14$ & $65.5(57.2-75.7)$ \\
\hline & 168 & $3.15 \pm 0.29$ & $40.8 \quad(32.3-47.2)$ \\
\hline \multirow[t]{4}{*}{$\mathrm{C} 87$} & 24 & $1.29 \pm 0.13$ & 589.6 (458.4-786.8) \\
\hline & 72 & $3.13 \pm 0.17$ & 78.6 (72.3-85.2) \\
\hline & 120 & $2.05 \pm 0.11$ & 58.6 (53.1-64.9) \\
\hline & 168 & $3.47 \pm 0.24$ & $36.1 \quad(33.0-39.3)$ \\
\hline \multirow[t]{4}{*}{ SM } & 24 & $1.35 \pm 0.10$ & $2398.2(1892.1-3244.1)$ \\
\hline & 72 & $2.46 \pm 0.23$ & $198.6(170.8-235.3)$ \\
\hline & 120 & $1.84 \pm 0.11$ & $80.4(70.6-92.9)$ \\
\hline & 168 & $2.76 \pm 0.20$ & $72.5 \quad(64.1-82.1)$ \\
\hline
\end{tabular}



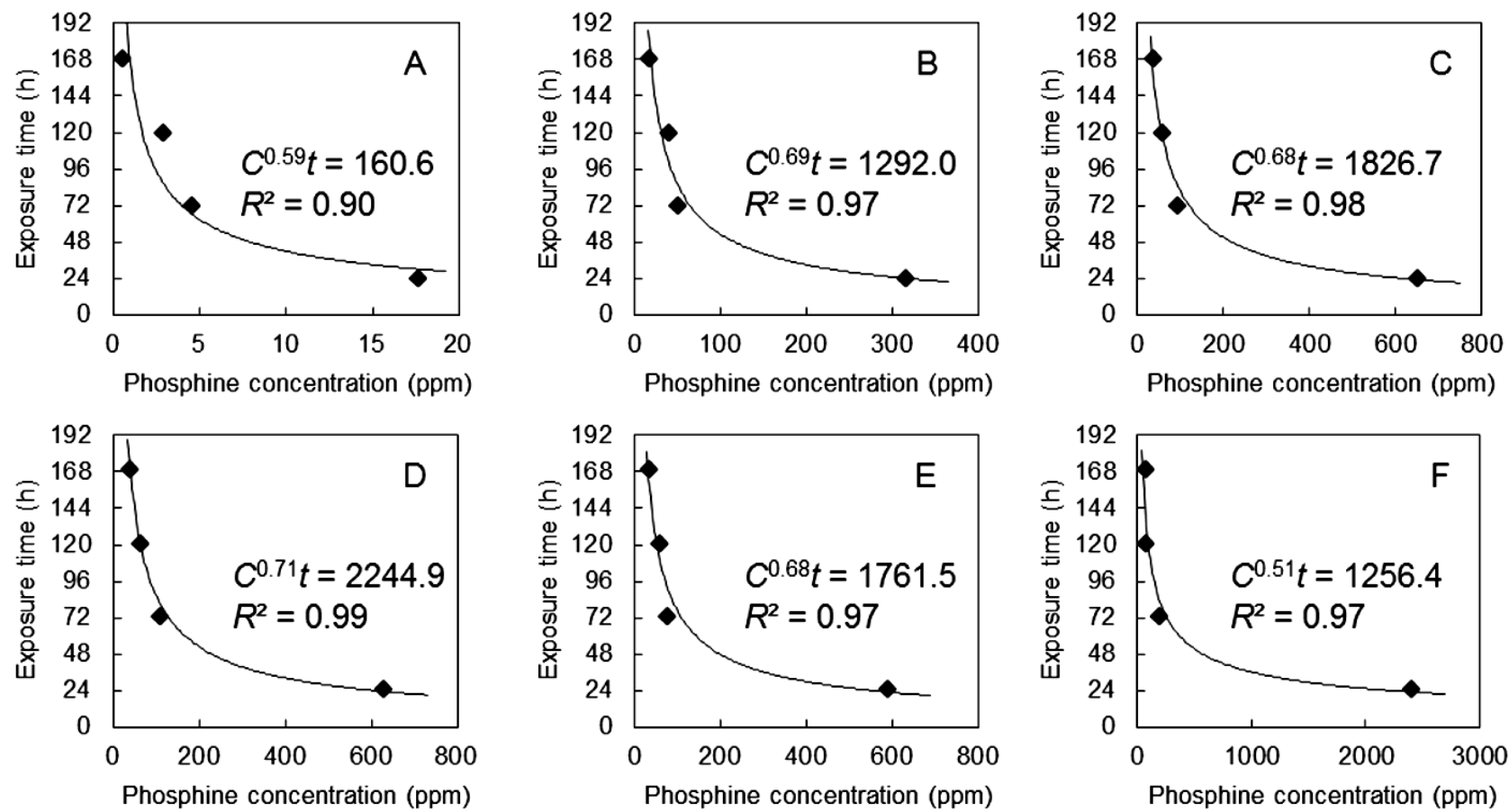

Figure 2. Relationship between phosphine concentration $(C)$ and exposure time $(t)$ at the respective $L C_{50}$ at $25{ }^{\circ} \mathrm{C}$ and $75 \%$ relative humidity for adults of Lasioderma serricorne cultures: A: TSC, B: THR, C: IWT, D: NGY, E: C87, and D: SM. The regression equations $C^{n} t=k$ and the coefficients of determination $\left(R^{2}\right)$ are given on the graphs.

\section{RESULTS AND DISCUSSION}

The adult's $\mathrm{LC}_{50}$ values of respective cultures ranged $17.8-2398.2 \mathrm{ppm}$ at $24-\mathrm{h}$ exposure, $4.6-198.6 \mathrm{ppm}$ at 72-h exposure, 3.0-80.4 ppm at 120-h exposure, and $0.6-72.5 \mathrm{ppm}$ at 168 -h exposure (Table 2). For all cultures the regression equation $C^{n} t=k$ provided a good description of the experimental phosphine concentration $(C)$ and exposure time $(t)$ at the respective $\mathrm{LC}_{50}$ (coefficient of determination 0.90-0.99; Figure 2). The values of $n$ in the regression equation were less than 1 for all the cultures $(0.51 \leq n \leq 0.71$; Figure 2), indicating the relative importance of exposure time over gas concentration in phosphine toxicity against $L$. serricorne adults, irrespective of phosphine susceptibility.

Phosphine has been widely used in tobacco industry since the mid-1970s. Similarly as with other insecticides, resistance has been selected by repeated fumigation under conditions far from ideal for success. Phosphine resistance in L. serricorne was first recorded in India and the United States in the 1990s $(7,8)$, and has spread globally with worldwide tobacco distribution. The tobacco industry has successfully managed the resistance problem to date by revising the industrial fumigation protocol (9). However, the industry has been encountering with increasing resistance (12) and it has become necessary to revise the fumigation protocols, one after another. The efficacy of phosphine is determined by three factors: concentration, time, and temperature and it is necessary to consider each of these three independent variables in adjusting the fumigation protocol for beetles showing a stronger resistance. To determine the fumigation protocol we need to investigate fumigation efficacy with different gas concentrations, time, and at different temperatures. In that case, the number of test settings (combination of concentration, time, and temperature) to be tried becomes enormous. However, if we know relative importance of each factor in fumigation efficacy, we can conduct investigations efficiently by focusing on the most important factor. This study revealed the relative importance of time over concentration in phosphine toxicity against the cigarette beetle. Therefore, it is suggested that extending the exposure time rather than increasing the concentration should be emphasized for future revision of fumigation protocols in order to successfully manage the resistance problem.

Longer exposure requires rigid gas-tightness of fumigation facilities to keep the prescribed concentration of phosphine. However, fumigation facilities for stored tobacco today not uncommonly transportation containers are used frequently do not meet the demands. In such a situation, the utilization of heating devices which enable to shorten the exposure time will become one resolution. The other is the introduction of gas-supply technologies which allow to add phosphine as needed. For this use, ready-to-use cylinderized formulation of phosphine may be desirable because it offers safer top-up operations compared with conventional solid metal phosphide, i.e., it is applicable externally, so that risk of worker exposure to phosphine is expected to decrease (13). Automated flow-through systems, which 
maintain or recirculate phosphine over long periods (14), may also be a solution for fumigation in non-gastight enclosures. Deployment of such devices in fumigation facilities will serve for the sustainable use of phosphine against the cigarette beetle.

\section{REFERENCES}

1. Haber, F.: Zur Geschichte des Gaskrieges; in: Fünf Vorträge aus den Jahren 1920-1923, edited by Springer, Berlin, Germany, 1924, pp. 76-92.

2. Winks, R.G.: The Toxicity of Phosphine to Adults of Tribolium castaneum (Herbst): Time as a Dosage Factor; J. Stored Prod. Res. 20 (1984) 45-56. DOI: 10.1016/0022-474X(84)90035-3

3. Winks, R.G. and C.J. Waterford: The Relationship Between Concentration and Time in the Toxicity of Phosphine to Adults of a Resistant Strain of Tribolium castaneum (Herbst); J. Stored Prod. Res. 22 (1986) 85-92. DOI: 10.1016/0022-474X(86)90024-X

4. Bell, C.H.: The Efficiency of Phosphine Against Diapausing Larvae of Ephestia elutella (Lepidoptera) Over a Wide Range of Concentrations and Exposure Times; J. Stored Prod. Res. 15 (1979) 53-58. DOI: 10.1016/0022-474X(79)90012-2

5. Bell, C.H.: Time, Concentration and Temperature Relationships for Phosphine Activity in Tests on Diapausing Larvae of Ephestia elutella (Hübner) (Lepidoptera: Pyralidae); Pestic. Sci. 35 (1992) 255-264. DOI: $10.1002 /$ ps.2780350310

6. Ho, S.H. and R.G. Winks: The Response of Liposcelis bostrychophila Badonnel and L. entomophila (Enderlein) (Psocoptera) to Phosphine; J. Stored Prod. Res. 31 (1995) 191-197. DOI: 10.1016/0022-474X(95)00005-R

7. Rajendran, S. and K.S. Narasimhan: Phosphine Resistance in the Cigarette Beetle Lasioderma serricorne (Coleoptera: Anobiidae) and Overcoming Control Failures During Fumigation of Stored Tobacco; Int. J. Pest. Manage. 40 (1994) 207-210. DOI: $10.1080 / 09670879409371883$

8. Zettler, J.L. and D.W. Keever: Phosphine Resistance in Cigarette Beetle (Coleoptera: Anobiidae) Associated with Tobacco Storage in the Southeastern United States; J. Econ. Entomol. 87 (1994) 546-550. DOI: $10.1093 /$ jee/ 87.3 .546

9. Cooperation Centre for Scientific Research Relative to Tobacco (CORESTA): Phosphine Fumigation Parameters for the Control of Cigarette Beetle and Tobacco Moth (Revised October 2013). Available at: https://www.coresta.org/sites/default/files/tech nical_documents/main/Guide-No02-Fumigation Oct13.pdf (accessed March 30, 2017)

10. Hori, M. and Y. Kasaishi: Development of a New Assay Method for Quickly Evaluating Phosphine Resistance of the Cigarette Beetle Lasioderma serricorne (Fabricius) (Coleoptera: Anobiidae), Based on Knockdown of the Adult Beetles; Appl. Entomol. Zool. 40 (2005) 99-104. DOI: 10.1303/aez.2005.99

11. Sakuma, M.: Probit Analysis of Preference Data; Appl. Entomol. Zool. 33 (1998) 339-347. Available at http://www.ars.usda.gov/News/docs.htm?docid=11284 DOI: $10.1303 /$ aez.33.339

12. Sağlam, Ö., P.A. Edde, and T.W. Phillips: Resistance of Lasioderma serricorne (Coleoptera: Anobiidae) to Fumigation With Phosphine; J. Econ. Entomol. 108 (2015) 2489-2495. DOI: $10.1093 /$ jee/tov 193

13. Tumambing, J., M. Depalo, J.P. Garnier, and R. Mallari: $\mathrm{ECO}_{2}$ Fume and Vaporph $_{3} \mathrm{OS}$ Phosphine Fumigants - Global Application Updates; in: Proceedings of the $9^{\text {th }}$ International Conference on Controlled Atmosphere and Fumigation in Stored Products, Antalya, Turkey, 15-19 October 2012, ARBER Professional Congress Services, Turkey, 2012, pp. 363-373. Available at: http://ftic.co.il/2012AntalyaPDF/SESSIO N.pdf (accessed March 30, 2017)

14. Winks, R.G. and G.F. Russell: Active Fumigation Systems: Better Ways to Fumigate Grain; in: Proceedings of the $5^{\text {th }}$ International Conference on Controlled Atmosphere and Fumigation in Stored Products, Nicosia, Cyprus, 21-26 April 1996, Printco Ltd., Cyprus, 1996, pp. 293-303. Available at: http://ftic.co.il/1996nicosiaPDF/CAF1996_Nicosia_0 01_721.pdf (accessed March 30, 2017)

Corresponding author:

Naoto Fukazawa

Leaf Tobacco Research Center

Japan Tobacco Inc.

Idei 1900, Oyama

Tochigi 323-0808

Japan

E-mail: naoto.fukazawa@jt.com 